\title{
Anti-diabetic Effects of Basil Extract (Ocimum basilicum) towards Hyeperglycemia in Gestational Diabetes Mellitus
}

\author{
Melisa Syafrina $^{1^{*}}$, Hirowati Ali ${ }^{2}$ and Rosfita Rasyid.Mkes ${ }^{3}$
}

${ }^{1}$ Biomedical Science, Faculty of Medicine, Andalas University, Padang 25138, Indonesia

${ }^{2}$ Biochemistry, Faculty of Medicine, Andalas University, Padang 25138, Indonesia

${ }^{3}$ Head of Master Program in Biomedical, Faculty of Medicine, Andalas University, Padang 25138, Indonesia

*Corresponding author

\section{A B S T R A C T}

\section{Keywords}

Basil, Gestational Diabetes Mellitus, Hyperglycemia

\section{Article Info}

Accepted:

05 January 2020

Available Online:

10 February 2020
Gestational Diabetes Mellitus is a disorder of carbohydrate tolerance that occurs or firstly known during pregnancy. Basil (Ocimum Basilicum) was reported as an herbal plant that contains active substances as antidiabetic drugs. This study aims at the antidiabetic effect of basil extract (ocimum basilicum) towards hyperglycemia in gestational diabetes mellitus. The research sample was carried out on 24 pregnant rats that induced streptozotosin $40 \mathrm{mg} / \mathrm{kg}$ BW. Samples were divided into 4 groups: negative control, positive control induced by streptozotosin, and 2 treatment groups induced by streptozotosin and given basil extract with doses of $100 \mathrm{mg} / \mathrm{kg} \mathrm{BW}$ and $200 \mathrm{mg} / \mathrm{kg} \mathrm{BW}$. Examination of blood glucose using a blood glucometer. From the results of this study, p value < 0,05 which means it was concluded that there was an effect of basil extract on the decrease in blood glucose.

\section{Introduction}

Gestational Diabetes Mellitus is a disorder of carbohydrate tolerance that occurs or firstly known during pregnancy. In 2017 the IDF estimates, gestational diabetes mellitus can affect around $14 \%$ of pregnancies worldwide which represent around 18 million births annually. During pregnancy, females undergoes changes in metabolism to meet the energy needs of the fetus.

Hyperglycemia occurs because pancreatic $\beta$ cells can not compensate for an increase in blood glucose during pregnancy (Salzer et al., 2014). 
Pancreatic $\beta$ cell dysfunction and insulin resistance are the main contributions of the pathophysiology of gestational diabetes mellitus (Barbour LA, 2007: Colomiere M, 2010).

Gestational diabetes mellitus can increase the risk of females and baby, including preeclampsia, preterem, cesarean section, macrosomia, shoulder dystocia and others (Wojcik Marzena, 2016).

Gestational diabetes mellitus can also increase the risk of T2DM after giving birth to the mother (Hunt Katharine F, 2014).

The role of oral hypoglycaemic agents (OHAs) in gestational diabetes is still controversial. According to the USA Food and Drug Administration (FDA) stated that, it does not recommend the used of OHAs during pregnancy (Hunt Katharine F, 2014).

O.basilicum extract was stated as an herbal plant that contains antidiabetic active substances, can reduce blood glucose, and is hepatoprotective so that it is useful for diabetics as an alternative treatment (ElBeshbishy, 2012; Yacout, 2012; Umar et al., 2012).

Basil has a complex chemical content consisting of glycosides, amino acids, tannins, phenolic compounds, steroids, triterpenoids, terpenoids, sterols, saponins, flavones and flavonoids (Bilal A et al., 2012).

Basil also has the effect of Anti-Oxidative stress, Anti-inflammatory effect, Antibacterial activity, Antioxidant capacity (Miraj Sepideh, et al., 2016).

The aim of this study was to look at the antidiabetic effect on gestational diabetes mellitus hyperglycemia.

\section{Materials and Methods}

\section{Animal}

Sampel 24 Female white rats (Rattus norvegicus L) with a weight of 180-250 grams from the animal laboratory at the Faculty of Pharmacy, Andalas University.

The treatment of experimental animals has received ethical approval from the Research Ethics Committee of the Andalas University Medical School. After 1 week, it was estimated that female rats were mated with male rats $(2: 1)$.

Females declared pregnant through vaginal smears. The sample was divided into 4 groups: the negative control group was pregnant without treatment, the positive control group was gestational diabetes mellitus, the other 2 groups were gestational diabetes mellitus treated with basil extract $100 \mathrm{mg} / \mathrm{kg}$ and 200 $\mathrm{mg} / \mathrm{kg} \mathrm{BW}$ for 14 days.

\section{Gestational diabetes mellitus induction}

Experimental animals were induced by $2 \%$ streptozotosin (STZ) (Bioworld, USA) $40 \mathrm{mg}$ / $\mathrm{kg}$ single dose subcutaneously on the first day after being declared pregnant.

Blood glucose was measured 72 hours after administration of STZ with blood glucose levels of $\geq 200 \mathrm{mg} / \mathrm{dl}-\leq 300 \mathrm{mg} / \mathrm{dl}$ (Aziz Abdul, et al., 2016: Wang Yuwei, et al., 2014).

\section{Preparation of crude extract}

Fresh basil samples collected as much as 3.5 $\mathrm{kg}$. Dried by aerating without direct sunlight for 15 days. Dried basil grinder into powder.

The powder was soaked with $96 \%$ ethanol $(1: 10)$ for 3 days in a closed vessel. The 
maserate was separated then the filtering results were thickened with a rotary evaporator at a temperature of around $630 \mathrm{C}$ to obtain a thick extract of $120 \mathrm{gr}$

Phytochemical test of basil extract (Harborne, 1996)

\section{Determination of flavonoids content}

As much as $40 \mathrm{mg}$ of extract was added to 100 $\mathrm{mL}$ of hot water, boil for 5 minutes, then filtered. $5 \mathrm{~mL}$ filtrate was added with $0.05 \mathrm{mg}$ $\mathrm{Mg}$ powder and $1 \mathrm{~mL}$ concentrated $\mathrm{HCl}$, then shaken vigorously. A positive test is indicated by the formation of red, yellow or orange.

\section{Determination of phenolics content}

As much as $40 \mathrm{mg}$ of extract was added 10 drops of $\mathrm{FeCl} 3$ 1\%. The extract signifies positively containing phenolic compounds if it produces purple, blue or jet black color.

\section{Determination of alkaloids content}

As much as $40 \mathrm{mg}$ of extract was added $2 \mathrm{~mL}$ of chloroform and $2 \mathrm{~mL}$ of ammonia then filtered. The filtrate is added 3 to 5 drops of concentrated $\mathrm{H} 2 \mathrm{SO} 4$ then shaken to form two layers.

The acid fraction is separated, then Mayer reagents are added 4-5 drops. If a precipitate forms, it indicates that the sample contains an alkaloid, with the Mayer reagent giving a white precipitate.

\section{Determination of saponins content}

As much as $40 \mathrm{mg}$ of extract was added 10 $\mathrm{mL}$ of water while being shaken for 1 minute, then added 2 drops of $\mathrm{HCl} 1 \mathrm{~N}$. If the foam formed remained stable \pm 7 minutes, then the positive extract contained saponins.

\section{Determination of steroids and triterpenoids Content}

As much as $40 \mathrm{mg}$ extract added 10 drops of glacial $\mathrm{CH} 3 \mathrm{COOH}$ and 2 drops of $\mathrm{H} 2 \mathrm{SO} 4$. The solution is shaken slowly and left for several minutes. Steroids give blue or green, while triterpenoids give red or purple.

\section{Statistical Analysis}

Data were analyzed using the One Way ANOVA test with a $\mathrm{p}$ value $<0.05$.

\section{Results and Discussion}

Phytochemical test results from basil ethanol extract (table 1). In this research, basil extract contents were tested which contained bioactive compounds such as flavonoids, phenolics (tannins), saponins, terpenoids, and steroids.

This was in line with research by Mboji (2014) and Dev et al (2011) which states that basil extract contains carbohydrates, glycosides, resins, saponins, tannins, terpenoids, steroids and various other phytochemicals.

Table.1 Phytochemicals of Basil Extract

\begin{tabular}{|c|c|}
\hline $\begin{array}{c}\text { Test } \\
\text { Parameters }\end{array}$ & $\begin{array}{c}\text { Etanol } \\
\text { Extract }\end{array}$ \\
\hline Alkaloid & - \\
\hline Flavonoid & + \\
\hline Fenolik & + \\
\hline Saponin & + \\
\hline Steroid & + \\
\hline Triterpenoid & + \\
\hline
\end{tabular}

From the results of statistical tests, the average blood glucose level decreased in the basil extract group $100 \mathrm{mg} / \mathrm{kg}$ and $200 \mathrm{mg} / \mathrm{kg}$ body weight compared with the positive control group (table 2) with a $\mathrm{p}$ value $=0,000$. 
It was because basil extract contains typical bioactive compounds that could improve dglucose homeostasis through inhibition of digestion and absorption of gastrointestinal carbohydrates, imitation of insulin and insulin sensitivity properties, without the risk of toxicity. Basil extract contains flavonoids which could provided inhibitory effects on the $\alpha$-glucosidase enzyme through hydroxylation bonds and strong inhibitor compounds towards the $\alpha$-amylase enzyme that functions for the breakdown of carbohydrates.

The inhibitory power of this enzyme causes the process of breaking down and absorption of carbohydrates will be disrupted, so that blood sugar levels could be reduced (Ridwan et al., 2012; Taufiqurohman, 2015).
A study by El-Beshbishy et al stated that the extract of Ocimum basilicum could inhibit the enzymes of a-glucosidase and a-amylase with minimum side effects. It was reported that dietary inhibitors a-glucosidase and a-amylase can modulate decreased glucose absorption in hyperglycemia (El-Beshbishy et al., 2012).

A similar research study was also carried out by Ezeani Chinelo et al (2017). in alloxaninduced diabetic rats showed that $100-400 \mathrm{mg}$ / $\mathrm{kg}$ of Ocimum basilicum (OB) extract can significantly reduce fasting blood glucose levels, increase oral glucose tolerance, and increase liver glycogen reserves through inhibition of $\alpha$-glucosidase and $\alpha$-amylase resulting in antihyperglycemic effect.

Table.2 Blood Glucose Levels

\begin{tabular}{|c|c|c|}
\hline $\begin{array}{l}\text { Subject } \\
\text { Group }\end{array}$ & $\begin{array}{c}\text { Day } 14 \text { of Glucose } \\
\text { Levels }\end{array}$ & P Value \\
\hline Negative control & $97,17 \mathrm{mg} / \mathrm{dl} \pm 4,45$ & \multirow[t]{4}{*}{0,000} \\
\hline Positive Control & $266 \mathrm{mg} / \mathrm{dl} \pm 16,09$ & \\
\hline Extract100 mg/kg & $144,33 \mathrm{mg} / \mathrm{dl} \pm 36,21$ & \\
\hline Extract $200 \mathrm{mg} / \mathrm{kg}$ & $112,83 \mathrm{mg} / \mathrm{dl} \pm 10,53$ & \\
\hline
\end{tabular}

\section{References}

Aziz Abdul Siti Hajar et al., 2016. Animal Model of Gestational Diabetes Mellitus with Pathophysiological Resemblance to the Human Condition Induced by Multiple Factors (Nutritional, Pharmacological, and Stress) in Rats. BioMed Research International Hindawi Publishing Corporation

Barbour LA, McCurdy CE, Hernandez TL, Kirwan JP, Catalano PM, Friedman JE. Cellular mechanisms for insulin resistance in normal pregnancy and gestational diabetes. Diabetes Care
2007; 30: S112-S119.

Colomiere M, Permezel M, Lappas M. Diabetes and obesity during pregnancy alter insulin signalling and glucose transporter expression in maternal skeletal muscle and subcutaneous adipose tissue. J Mol Endocrinol 2010; 44: 213-223.

Dev N, A. K. Das, M. A. Hossain and S. M. M. Rahman,. 2011. Chemical Compositions of Different Extracts of Ocimum basilicum Leaves. Journal Of Scientific Research.:201

El-Beshbishy, H., \& Bahashwan, S. 2012. Hypoglycemic effect of basil (Ocimum basilicum) aqueous extract is mediated 
through inhibition of alpha-glucosidase and alpha-amylase activities An in vitro study. Toxicology and Industrial Health, 28(1), 42-50.

Ezeani Chinelo et al., 2017 .Ocimum basilicum extract exhibits antidiabetic effects via inhibition of hepatic glucose mobilization and carbohydrate metabolizing enzymes. Journal of Intercultural Ethnopharmacology. Vol 6 Issue 1 Expert.

Hunt F Katharine, Benjamin C Whitelaw, Carol Gayle. 2014. Gestational Diabetes Obstetrics, Gynaecology And Reproductive Medicine.

International Diabetes Federation. IDF Diabetes Atlas, 8th ed.; IDF: Brussels, Belgium, 2017.

Mbaoji F. N., C. O. Okoli and A. C. Ezike. 2014. Preliminary antihyperglycemic activity-guided studies on the leaf extract and fractions of Ocimum basilicum L. Journal of Chemical and Pharmaceutical Research, 575-580

Miraj Sepideh and Sadegh Kiani,. 2016. Study of pharmacological effect of Ocimum basilicum", Scholars Research Library. 276-280

Ridwan, A., Astrian, R. T. and Barlian, A. 2012. Pengukuran efek antidiabetes polifenol (polyphenon 60) berdasarkan kadar glukosa darah dan histologi pankreas mencit (Mus musculus) s.w. jantan yang dikondisikan diabetes mellitus. Jurnal Matematika dan Sains, 17(2) pp.78-82.

Salzer Liat, MD, Kinneret Tenenbaum-
Gavish, MD, Moshe Hod, MD. 2014. Metabolic disorder of pregnancy (understanding pathophysiology of diabetes and preeclampsia). Best Practice \& Research Clinical Obstetrics and Gynaecology xxx. 1-11

Taufiqurohman. 2015. Indonesian Bay Leaves as Antidiabetic for Type 2 Diabetes Mellitus. J. MAJORITY, 4(3) pp.101108.

Umar, I. A, et al., 2012. The hypolipidemic and antioxidant actions of aqueous extracts of Ocimum basilicum and Ocimum suave in high fat fed Rats. Journal of Medicinal Plants Research, $6(18), 5$

Wang Yuwei et al., 2014. The Therapeutic Effect of Zuogui Wan in Gestational Diabetes Mellitus Rats. Journal of Analytical Methods in Chemistry. Hindawi Publishing Corporation. Volume 2014, Article ID 737961, 6 pages

Wojcik Marzena, Andrzej Zieleniak, Monika Zurawska-Klis, Katarzyna Cypryk and Lucyna Alicja Wozniak. 2016. Increased expression of immune-related genes in leukocytes of patients with diagnosed gestational diabetes mellitus (GDM). Experimental Biology and Medicine 2016; 241: 457-465

Yacout G, Elguindy N, Azab E. 2012. Hepatoprotective effect of basil (Ocimum basilicum L.) On $\mathrm{CCl}_{4^{-}}$ induced liver fibrosis in rats. Afr $\mathrm{J}$ Biotech;11.

\section{How to cite this article:}

Melisa Syafrina, Hirowati Ali, Rosfita Rasyid.Mkes. 2020. Anti-diabetic Effects of Basil Extract (Ocimum basilicum) towards Hyeperglycemia in Gestational Diabetes Mellitus. Int.J.Curr.Microbiol.App.Sci. 9(02): 6-10. doi: https://doi.org/10.20546/ijcmas.2020.902.002 